\title{
The Status of Floristic Analysis of Mt. Pangasugan, Leyte, Philippines - a Conservation Priority Area Classified as "Extremely High Critical"
}

\author{
Gerhard Langenberger ${ }^{1}$ and Beatriz S. Belonias ${ }^{2}$ \\ ${ }^{1}$ University of Hohenheim, Institute of Plant Production and Agroecology in the \\ Tropics and Subtropics (380b), 70593 Stuttgart, Germany; ${ }^{2}$ Department of Biological \\ Sciences, Visayas State University, Visca, Baybay City, Leyte, 6521-A Philippines
}

\begin{abstract}
The island of Leyte in the Eastern Visayas takes a central position between the Philippine main islands of Luzon and Mindanao. It is characterized by the Leyte Cordillera, which is part of the Philippine fault line. Within the Leyte Cordillera, Mt. Pangasugan takes an exceptional role since it provides a catena from lowland forest remnants on its foothills to mossy forest on its summit at $1158 \mathrm{~m}$ a.s.1.. Recently, Mt. Pangasugan has been identified as conservation priority area classified as of "extremely high critical' level.

Mt. Pangasugan has been the focus of comprehensive botanical studies within the last few years. We present the current status of the floristic assessment of the mountain and introduce the Visayas State University Herbarium, located at the foot of Mt. Pangasugan, where the majority of collected specimens are deposited. At present, the Herbarium houses c. 6100 specimens, 3000 of them originating from the primary forest of Mt. Pangasugan. Based on the present status of specimen processing and identification they represent 115 families, and 418 genera of Angiosperms, 2 families, 2 genera, and 3 species of Gymnosperms, 27 families and 64 genera of Pteridophytes, and 3 classes, 38 genera and 51 species of Bryophytes. The number of vascular plant species represented in the VSU Herbarium can safely be estimated at c. 800-1000. Given the small overall sampling area intensively studied so far these figures can be assumed as representing just a fraction of the total floristic richness of the area.
\end{abstract}

Keywords: bryophytes, spermatophytes, pteridophytes, Leyte Cordillera, plant collections, vascular plant species

Correspondence: G. Langenberger Address: University of Hohenheim, Institute of Plant Production and Agroecology in the Tropics and Subtropics (380b), 70593 Stuttgart, Germany Email: langenbe@uni-hohenheim.de

DOI: 10.32945/atr3321.2011 


\section{INTRODUCTION}

The Philippines has been acknowledged as important megadiversity hot spot in Southeast Asia (Myers et al., 2000). It harbors c. 8120 angiosperm, 33 gymnosperm, and 1031 pteridophyte species (DENR and UNEP, 1997). The archipelago had been a center of comprehensive floristic studies at the beginning of the last century as has been documented by van Steenis (1950). Nevertheless, compared to the neighboring countries the flora of the Philippines is still little known as has been stressed by Kartawinata (1990), Soerianegara and Lemmens (1994), or Frodin (2001).

The Philippine archipelago is dominated by its two main islands which make up two thirds of the land surface, Luzon in the north and Mindanao in the south. The two islands are testimonies of the plantgeographic evolution in Southeast Asia. While the Philippines are basically characterized by Malaysian plant groups the vegetation of Luzon shows distinct floristic impacts from continental Asia as e.g. the two pine species Pinus khesya and Pinus merkusii or representatives of the higher latitude family Gentianaceae. Mindanao, on the other hand, shows the impact of Australian floristic elements, like the northernmost occurrence of the genus Eucalyptus (E. deglupta) (Dickerson, 1928, Merrill, 1945). Leyte and Samar form the central island group between these two entries of plant invasions. A better knowledge of their vegetation will improve our understanding of plant geographic processes in the Philippine archipelago.

On the island of Leyte, Mt. Pangasugan has been the focus of several comprehensive plant biodiversity studies. It is a distinct mountain on the west coast of the island. At its foot the Visayas State University (VSU) is located. VSU usually acts as base camp for floristic studies and inventories on the mountain. During a nationwide biodiversity prioritysetting workshop Mt. Pangasugan and its environs have been identified as a conservation priority area of an "extremely high critical" level (Ong et al., 2002, p. 90). However, despite this declaration, Mt. Pangasugan's biodiversity is continually threatened e.g. by mining activities.

Within this paper we present the floristic studies conducted on Mt. Pangasugan and give an overview of the plant taxa so far identified. 
Additionally, we introduce the Visayas State University Herbarium, where most of the collections are deposited. The objective of this paper is to add to the knowledge of the Philippine flora as well as to focus the scientific as well as public view on this exceptional mountain.

\section{The Island of Leyte and Mt. Pangasugan}

The island of Leyte belongs to the biogeographic region of the Eastern Visayas (DENR and UNEP 1997). Together with the island of Samar it takes a central position between the Philippine main islands of Luzon and Mindanao (Figure 1).

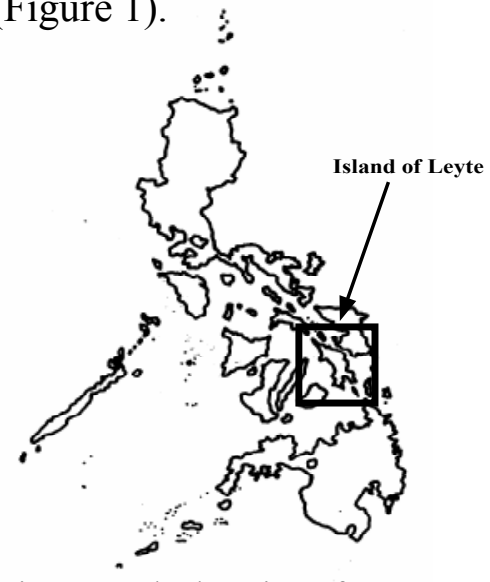

Figure 1. The location of Leyte

With $7448 \mathrm{~km}^{2}$ Leyte is the eighth biggest island in the Philippine archipelago. It extends over a length of c. $214 \mathrm{~km}$ between $9^{\circ} 55^{\prime}$ and $11^{\circ} 48^{\prime}$ northern latitude, and between $124^{\circ} 17^{\prime}$ and $125^{\circ} 18^{\prime}$ eastern longitude. At its 'hip' it is only $25 \mathrm{~km}$ wide (Figure 2 ).

Leyte is a rugged and mountainous island. Its characteristic feature is the Leyte Cordillera, which belongs to the Philippine fault line and extends north to south over the whole length of the island. Due to its rugged relief and the resulting difficult accessibility pristine forests can still be found even in rather close vicinity to the densely populated coastal planes. A good example is Mt. Pangasugan (10 $44^{\prime} \mathrm{N}, 124^{\circ} 48^{\prime}$ E) on the western side of the island, which faces the Camotes Sea. It is located c. $8 \mathrm{~km}$ north of the provincial capital of Baybay and c. $34 \mathrm{~km}$ 


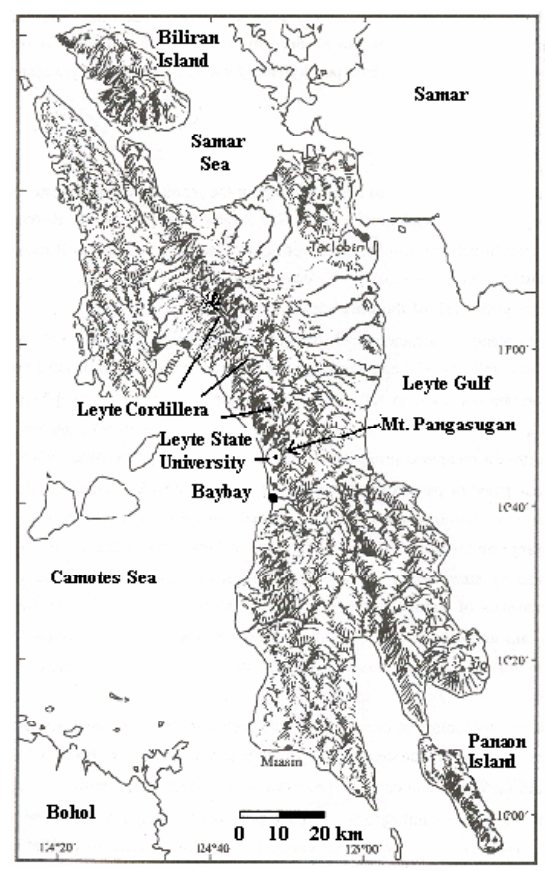

Figure 2. Leyte and the location of Mt. Pangasugan and the Visayas State University

south of Ormoc City. On the narrow coastal plane at its foot the Visayas State University (VSU) is located. Mt. Pangasugan is exceptional since it still provides a catena from lowland forest remnants on its foothills to mossy forest on its summit at c. $1158 \mathrm{~m}$ a.s.1.

Geologically, the bulk of Leyte consists of andesitic, basaltic and dacitic flows and breccia of Miocene age covered with lava flows and volcanoclastics (Asio, 1996). On the western foothills of Mt. Pangasugan at c. $400-500 \mathrm{~m}$ a.s.1. soil studies revealed dacitic and andesitic breccia as parent material and Haplic Andosols as the resulting soil (Zikeli, 1998).

Climatically, Leyte is characterized by a tropical monsoon climate, with no pronounced dry season (Kintanar, 1984). Calculations based on data from the PAGASA ${ }^{1}$ Weather Station $(7 \mathrm{~m})$ on the Campus of the Visayas State University showed an annual average temperature of $27.4^{\circ} \mathrm{C}$ and an average annual precipitation of $2586 \mathrm{~mm}$. Although, on

${ }^{1}$ Philippine Athmospheric, Geophysical and Astronomical Services Administration 
average, no dry season occurs, rainfall distribution is not homogenous, and March to May receive with monthly $95 \mathrm{~mm}$ to $133 \mathrm{~mm}$ much less precipitation than November to January with $284 \mathrm{~mm}$ to 296 $\mathrm{mm}$. Nevertheless, the variability of precipitation is high, and severe drought periods can be observed during El Niño Southern Oscillation Years (Langenberger, 2003). The contribution of orographic rains and clouds to the precipitation on the mountain slopes and summit has never been studied. But both definitely play an important role for vegetation development. Another important feature of the area is the occurrence of typhoons and the often associated landslides.

\section{The Visayas State University (VSU) Herbarium and its Collections}

The Visayas State University (VSU) Herbarium is a small but growing university herbarium affiliated to the university's Department of Biological Sciences (DBS). It has been formally established in 1990 within the framework of a cooperation project between the Philippines and Germany ${ }^{2}$. The project was launched to improve the ecological conditions on Leyte. The task of the Herbarium is to act as a repository of voucher specimens from plant biodiversity studies on Mt. Pangasugan.

The Herbarium consists of a storage room with steel and glass cabinets and built-in hanging cupboards for storing herbarium specimens. It also has a working room equipped with work tables, pressers, two drying boxes, and a stereoscope, as well as a small taxonomic library. The Herbarium has been managed by the staff of the Department of Biological Sciences and has been operating initially using research funds from the cooperation project. At present, a very small part of the department's annual budget allocation sustains the unit in terms of needed supplies. Occasional support from collaborative researches of VSU staff and visiting scientists also help to improve the facility. The absence of a full-time staff in the Herbarium and the lack of important equipment like air-conditioner, or a computer, hamper its further development.

2 "Philippine-German Environmental Research and Development Program", PN 88.2122.5-01.100 
Insufficient taxonomic references are also a major problem.

Based on the current status of specimen processing and identification, the Herbarium houses a total of c. 5500 mounted specimens collected from various parts of Leyte Island, about 3000 of which come from the primary forests of Mt. Pangasugan. Around 1000 specimens were collected from other parts of Leyte, like Lake Danao in Ormoc, Mt. Lobi in Dagami and other localities on the island.

A considerable number (c. 2000) are backlog specimens that are already mounted but still need to be catalogued and identified. Furthermore, there are still collections especially from Mt. Janagdan, Ormoc, awaiting processing and final identification. Table 1 provides a summary of the present collection of the VSU Herbarium.

Table 1. The VSU Herbarium and its Collections

\begin{tabular}{lc}
\hline \multicolumn{1}{c}{ Collection localities } & Number of specimens* \\
\hline Mt. Pangasugan & c. 3000 \\
Mt. Janagdan, Ormoc (not yet processed) & c. 600 \\
Other localities on Leyte & c. 1000 \\
Miscellanious (students' collections, exotics, etc.) & c. 1500 \\
Total no. of specimens & c. $\mathbf{6 1 0 0}$ \\
\hline
\end{tabular}

*A considerable number of specimens has not yet been included in the data base. Therefore no exact figures are given.

\section{Floristic research conducted on Mt. Pangasugan}

First plant collections on the island of Leyte are documented for the beginning of the $20^{\text {th }}$ century, e.g. by Cuming, Warburg, or Jagor (van Steenis, 1950). Since then floristic activities on Leyte have been rare as can be seen from the overview by Madulid and Agoo (1992). Neither van Steenis (1950) nor Madulid and Agoo (1992) mention Mt. Pangasugan as research or collection site.

But since the early 1990's Mt. Pangasugan has been the focus of comprehensive plant biodiversity studies. Floristic inventories of bryophytes and vascular plants were done by graduate students, visiting scientists and faculty researchers of the university. Except for the studies by Po (2000), Belonias (2002), and Langenberger (2003), 
which were done primarily in the primary forests of Mt. Pangasugan, all other inventories included native, introduced as well as cultivated species. Since their results do not provide information relevant for an ecological evaluation of Mt. Pangasugan`s flora, they are not considered here. In 1992, there was also a floristic trip by the Philippine National Herbarium within the framework of the Flora of the Philippines Project. 30 specimens of that exploration are deposited at the VSU Herbarium. In Tables 4-6 we list all families and genera of spermatophytes (Table 4), pteridophytes (Table 5), and musci (Table 6) identified in the studies cited in table 2. We did not go down to species level. Due to the lack

Table 2. Floristic Studies Conducted on Mt. Pangasugan, Leyte, Philippines

\begin{tabular}{|c|c|c|}
\hline Researcher \& Year & Plant groups studied & No. of taxa identified \\
\hline Langenberger 2003 & Vascular plants & $\begin{array}{c}111 \text { families, } 289 \text { genera, } \\
685 \text { species }\end{array}$ \\
\hline Belonias 2002 & Dicotyledons & $\begin{array}{c}75 \text { families, } 212 \text { genera, } 314 \\
\text { species }\end{array}$ \\
\hline Po 2000 & Monocotyledons & $\begin{array}{l}14 \text { families, } 51 \text { genera, } 77 \\
\text { species }\end{array}$ \\
\hline Belonias \& Bañoc 1994 & Pteridophytes & $\begin{array}{c}24 \text { families, } 55 \text { genera, } 93 \\
\text { species }\end{array}$ \\
\hline Quimio 1994 & Bryophytes & $\begin{array}{c}3 \text { classes, } 38 \text { genera, } 51 \\
\text { species }\end{array}$ \\
\hline
\end{tabular}

of an updated taxonomic reference of Philippine vascular plants the problem of the application of synonyms and outdated names is abundant. A sound combination of the results of different studies would require a comprehensive check to avoid the use of such synonyms and to apply the same taxonomic classification system. Given the available resources this was not possible for all plant groups so far encountered. We therefore decided to stick to the family and generic level to avoid the impression of an accuracy which cannot be guaranteed at present. Additionally, this avoids the problem of how to tread morpho-species. Family and genus delimitation for spermatophytes follows the compilation by Gunn et al. (1992). For the Pteridophytes the classification scheme applied by Salgado (1990) in his checklist has been used to standardize the use of 
family and genera names. In Table 3 the results for the vascular plants are given. So far 144 families and 484 genera of vascular plants have been identified for Mt. Pangasugan. In Figure 3 we present the 35 most common spermatophyte families concerning the number of genera. With 33 genera the Rubiaceae are by far the most genus-rich family. They are

Table 3. No. of Vascular Plants so far documented for Mt. Pangasugan*

\begin{tabular}{lccc}
\hline & Spermatophytes & Pteridophytes & Total \\
\hline Families: & 117 & 27 & 144 \\
Genera: & 420 & 64 & 484 \\
*The figures for the spermatophytes and pteridophytes are the result of a synthesis of the \\
studies by Belonias \& Bañoc (1994), Po (2000), Belonias 2002, and Langenberger (2003); the \\
figures for the musci are from Quimio (1994)
\end{tabular}

followed by the mostly epiphytic orchids with 27 genera. Concerning terrestrial plants the Euphorbiaceae are second. Both terrestrial families rarely represent dominant trees. Mostly, their representatives are medium to small trees or shrubs. This stresses the importance of the undergrowth for the overall species richness in the area.

\section{CONCLUSIONS}

The importance of detailed local botanical studies has been stressed by Prance et al. (2000). Concerning the vascular plant taxa represented in this paper (Tables 4 and 5) it has to be noted that the numbers are mainly based on plot sampling covering an overall area of less than 1 ha. This is a tiny fraction of the still existing forest on Mt. Pangasugan, leave alone the Leyte Cordillera. From our current overview of the collections at the VSU Herbarium we estimate that they certainly represent 800 to 1000 vascular plant species. That the encounter of new or very rare taxa is just a matter of collecting can be seen from the findings of the last collections. Four new orchid species have been described from Mt. Pangasugan in the years 1996 to 1998 (Fessel and Lückel, 1996a, b, 1997, 1998). The Schefflera specimens (Araliaceae) at the VSU Herbarium contain one species, S. leytensis (GL 2462), which has been collected only once before, several decades ago, as well as three species still awaiting final 


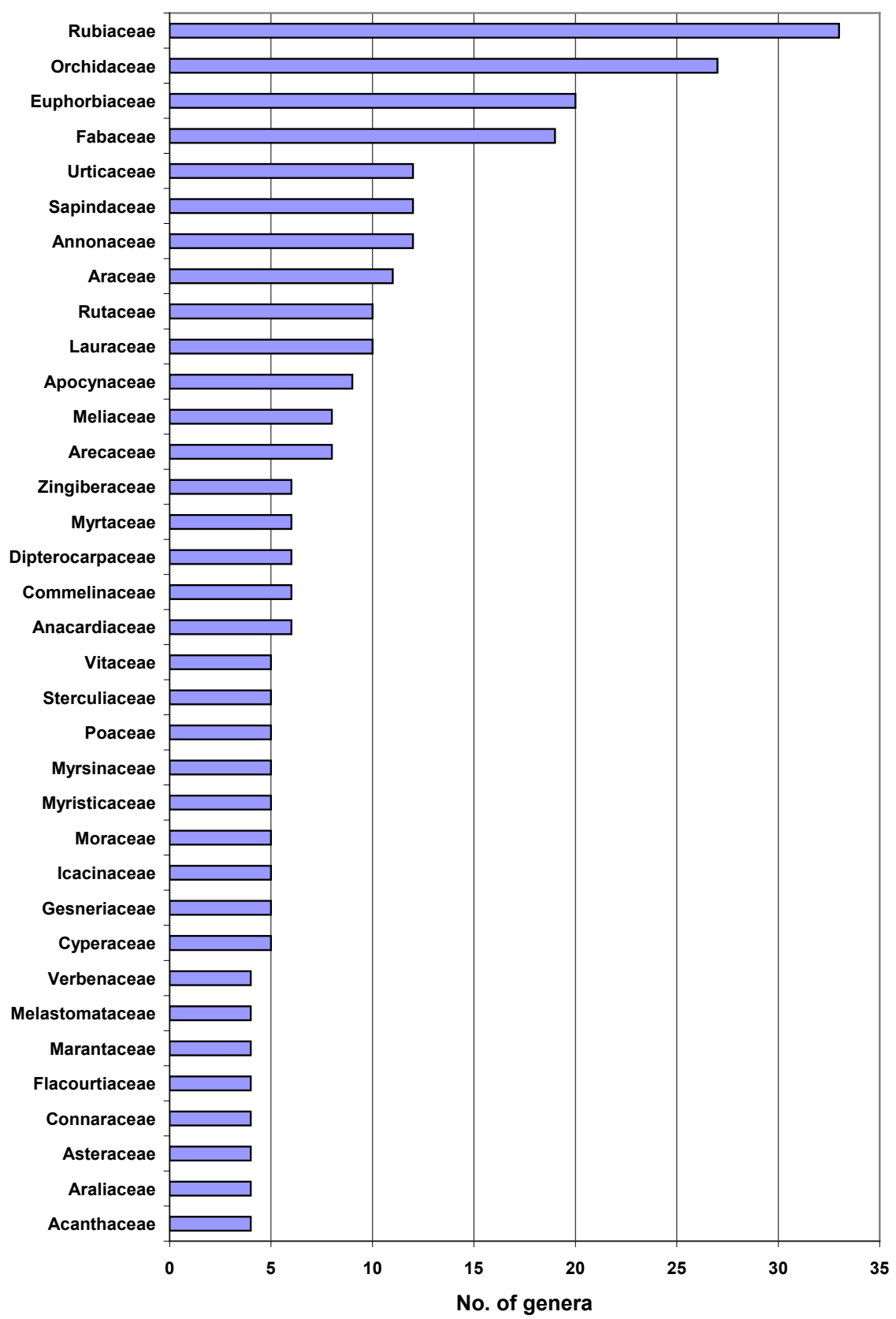

Figure 3. The most common spermatophyte families on Mt. Pangasugan, Leyte, Philippines, as based on the current status of floristic analysis 
Table 4. Families and genera of spermatophytes identified on Mt. Pangasugan based on the synthesis of the studies by Po (2000), Belonias (2002), and Langenberger (2003)

Acanthaceae (4)*

Acanthus

Hemigraphis

Justicia

Strobilanthes

Aceraceae (1)

Acer

Actinidiaceae (1)

Saurauia

Alangiaceae (1) Ilex

Alangium

Amaranthaceae (2)

Achyranthes

Deeringia

Anacardiaceae (6)

Dracontomelon

Koordersiodendron

Mangifera

Rhus

Semecarpus

Spondias

Annonaceae (12)

Alphonsea

Anaxagorea

Artabotrys

Cananga

Cyathocalyx

Goniothalamus

Meiogyne

Papualthia

Platymitra

Polyalthia

Popowia

Uvaria
Apocynaceae (9)

Alstonia

Alyxia

Dischidia

Kibatalia

Lepiniopsis

Paralstonia

Tabernaemontana

Voacanga

Wrightia

Aquifoliaceae (1)

Araceae (11)

Aglaonema

Alocasia

Amorphophallus

Costus

Homalomena

Pothoidium

(Araceae cont.)

Pothos

Raphidophora

Schismatoglottis

Scindapsus

Spadiphyllum

Araliaceae (4)

Arthrophyllum

Osmoxylon

Polyscias

Schefflera

Arecaceae (8)

Arenga

Calamus

Caryota

Daemonorops

Korthalsia
(Arecaceae cont.)

Oncosperma

Pinanga

Heterospathe

Aristolochiaceae (1)

Aristolochia

Asclepiadaceae (2)

Gymnema

Hoya

Asteraceae (4)

Ageratum

Blumea

Mikania

Vernonia

Balanophoraceae (1)

Balanophora

Begoniaceae (1)

Begonia

Bignoniaceae (2)

Oroxylum

Radermachera

Burseraceae (2)

Canarium

Dacryodes

Capparidaceae (1)

Capparis

Caprifoliaceae (2)

Sambucus

Viburnum 
Table 4. Families and genera of spermatophytes identified on Mt. Pangasugan based on the synthesis of the studies by Po (2000), Belonias (2002), and Langenberger (2003) (cont.)

Casuarinaceae (1)

Gymnostoma

Cecropiaceae (2)

Poikilospermum

Procris

Bhesa

Celastraceae (3)

Euonymus

Lophopetalum

Chloranthaceae (2)

Chloranthus

Sarcandra

Chrysobalanaceae (1)

Maranthes

Clethraceae (1)

Clethra

Clusiaceae (3)

Calophyllum

Garcinia

Kayea

Combretaceae (1)
Terminalia

Commelinaceae (6)

Aneilema

Cyanotis

Floscope

Forrestia

Pollia

Rhopalephora

Connaraceae (4)

Cnestis

Connarus
(Connaraceae cont.)

Ellipanthus

Rourea

\section{Crypteroniaceae (1) Elaeagnus}

Crypteronia

Cucurbitaceae (1)

Trichosanthes

Cunoniaceae (1)

Weinmannia

Cyperaceae (5)

Carex

Hypolytrum

Mapania

Paramapania

Scleria

Datiscaceae (1)

Octomeles

Dichapetalaceae (1)
Dichapetalum

Dilleniaceae (2)

Dillenia

Tetracera

Dioscoreaceae (2)

Dioscorea

Stenomeris

Dipterocarpaceae (6)

Anisoptera

Dipterocarpus

Hopea

Parashorea

Shorea

Vatica
Ebenaceae (1)

Diospyros

Elaeagnaceae (1)

Elaeocarpaceae (1)

Elaeocarpus

Ericaceae (2)

Rhododendron

Vaccinium

Euphorbiaceae (20)

Acalypha

Antidesma

Aporosa

Baccaurea

Breynia

Bridelia

Claoxylon

Cleidion

Cleistanthus

Codiaeum

Croton

Drypetes

Glochidion

Macaranga

Mallotus

Neotrewia

Omalanthus

Phyllanthus

Suregada

Trigonostemon

Albizia

Afzelia

Archidendron

Fabaceae (19) 
Table 4. Families and genera of spermatophytes identified on Mt. Pangasugan based on the synthesis of the studies by Po (2000), Belonias (2002), and Langenberger (2003) (cont.)

(Fabaceae cont.)

Bauhinia

Dalbergia

Derris

Desmodium

Entada

Erythrina

Euchresta

Kingiodendron

Milletia

Mucuna

Ormosia

Pithecelobium

Pterocarpus

Spatholobus

Strongylodon

Wallaceodendron

Fagaceae (1)

Lithocarpus

Flacourtiaceae (4)

Casearia

Homalium

Osmelia

Trichadenia

Flagellariaceae (1)

Flagellaria

Gesneriaceae (5)

Aeschynanthus

Cyrtandra

Agalmyla

Monophyllaea

Rhynchoglossum

Gnetum
Grossulariaceae (2)

Itea

Polyosma

Hamamelidaceae (1)

Sycopsis

Hernandiaceae (1)

Illigera

Hydrangeaceae (1)

Hydrangea

Icacinaceae (5)

Gomphandra

Gonocaryum

Miquelia

Phytocrine

Platea

Ixonanthaceae (1)

Ixonanthes

Juglandaceae (1)

Engelhardia

Lamiaceae (1)

Gomphostemma

Lauraceae (10)

Actinodaphne

Caryodaphnopsis

Cinnamomum

Cryptocarya

Dehaasia

Endiandra

Litsea

Neolitsea

Notaphoebe

Phoebe
Leeaceae (1)

Leea

Lecythidaceae (2)

Petersianthus

Planchonia

Liliaceae (2)

Curculigo

Dianella

Fagraea

Geniostoma

Strychnos

Magnoliaceae (1)

Magnolia

Malpighiaceae (1)

Hiptage

Marantaceae (4)

Donax

Phacelophrynium

Phrynium

Stachyphrynium

Melastomataceae (4)

Astronia

Medinilla

Melastoma

Memecylon

Meliaceae (8)

Aglaia

Aphanamixis

Chisocheton

Dysoxylum

Reinwardtiodendron 
Table 4. Families and genera of spermatophytes identified on Mt. Pangasugan based on the synthesis of the studies by Po (2000), Belonias (2002), and Langenberger (2003) (cont.)

(Meliaceae cont.)

Toona

Vavaea

Walsura

Menispermaceae (3)

Arcangelisia

Pycnarrhena

Tinomiscium

Monimiaceae (2)

Kibara

Matthaea

Moraceae (5)

Artocarpus

Ficus

Maclura

Trophis

Streblus

Musaceae (1)

Musa

Myristicaceae (5)

Endocomia

Gymnacranthera

Horsfieldia

Knema

Myristica

Ardisia

Myrsinaceae (5)

Discocalyx

Embelia

Maesa

Myrsine
Myrtaceae (6)

Acmena

Decaspermum

Syzygium

Tristaniopsis

Xanthomyrtus

Xanthostemon

Nepenthaceae (1)

Nepenthes

Gomphia

Ochnaceae (1)

Olacaceae (2)

Erythropalum

Strombosia

Oleaceae (1)

Olea

Opiliaceae (2)

Champereia

Melientha

Orchidaceae (27)

Acanthephippium

Aphyllorchis

Appendicula

Bulbophyllum

Calanthe

Ceratostylis

Coelogyne

Cymbidium

Dendrobium

Dendrochilum

Epigeneium

Eria

Erythrodes

Eulophia
(Orchidaceae cont.)

Flickingeria

Galeola

Grammatophyllum

Grastidium

Habenaria

Lepidogyne

Liparis

Luisia

Phalaenopsis

Plocoglottis

Robiquetia

Spathoglottis

Trichoglottis

Pandanaceae (2)

Freycinetia

Pandanus

Pentaphragmataceae (1)

Pentaphragma

Piperaceae (2)

Peperomia

Piper

Pittosporaceae (1)

Pittosporum

Poaceae (5)

Bambusa

Centotheca

Dinochloa

Schizostachyum

Thysanonlaena

Podocarpaceae (1)

Podocarpus 
Table 4. Families and genera of spermatophytes identified on Mt. Pangasugan based on the synthesis of the studies by Po (2000), Belonias (2002), and Langenberger (2003) (cont.)

$$
\text { Polygalaceae (2) }
$$

Polygala

Xanthophyllum

Proteaceae (1)
Helicia
Ranunculaceae (1)
Clematis
Rhamnaceae (3)
Sageretia
Ventilago
Ziziphus
Rhizophoraceae (1)
Gynotroches

Rosaceae (2)
Prunus
Rubus

Adina

Rubiaceae (33)

Argostemma

Boholia

Borreria

Canthium

Diodia

Diplospora

Dolicholobium

Gardenia

Greeniopsis

Hedyotis

Hydnophytum

Hypobathrum

Ixora

Lasianthus

Morinda
(Rubiaceae cont.)

Mussaenda

Mycetia

Myrmecodia

Nauclea

Neonauclea

Ophiorrhiza

Pavetta

Pertusadina

Praravinia

Psychotria

Tarenna

Tarrenoidea

Timonius

Uncaria

Urophyllum

Wendlandia

Xanthophytum

Rutaceae (10)

Achronychia

Atalantia

Clausena

Euodia

Glycosmis

Lunasia

Melicope

Micromelum

Severinia

Zanthoxylum

Sabiaceae (1)

Meliosma

Sapindaceae (12)

Allophylus

Cubilia

Dictyoneura

Dimocarpus

Euphorianthus

Ganophyllum
(Sapindaceae cont.)

Guioa

Harpullia

Lepisanthes

Nephelium

Paranephelium

Pometia

Sapotaceae (3)

Palaquium

Planchonella

Pouteria

Saxifragaceae (2)

Dichroa

Polyosma

Simaroubaceae (1)

Picrasma

Smilacaceae (1)

Smilax

Solanaceae (1)

Solanum

Sonneratiaceae (1)

Duabanga

Staphyleaceae (1)

Turpinia

Sterculiaceae (5)

Heritiera

Melochia

Pterocymbium

Pterospermum

Sterculia

Symplocaceae (1)

Symplocos 
Annex 1: Families and genera of spermatophytes identified on Mt. Pangasugan based on the synthesis of the studies by Po (2000), Belonias (2002), and Langenberger (2003) (cont.)

Taccaceae (1)

Tacca

\begin{tabular}{|c|c|}
\hline & Elatostematoides \\
\hline Theaceae (2) & Girardinia \\
\hline Eurya & Laportea \\
\hline Ternstroemia & Leucosyke \\
\hline & Maoutia \\
\hline Thymelaeaceae (3) & Oreocnide \\
\hline Aquilaria & Pilea \\
\hline Gonystylus & Pipturus \\
\hline Phaleria & Pouzolzia \\
\hline Tiliaceae (3) & Verbenaceae (4) \\
\hline Colona & Clerodendrum \\
\hline Grewia & Premna \\
\hline Microcos & $\begin{array}{l}\text { Teijsmanniodendron } \\
\text { Vitex }\end{array}$ \\
\hline
\end{tabular}

Celtis

Gironniera

Trema

Urticaceae (12)

Cypholophus

Dendrocnide
(Urticaceae cont.)

Elatostema

Elatostematoides

Laportea

Leucosyke

Maoutia

Pilea

Pipturus

Verbenaceae (4)

Vitaceae (5)

Ampelocissus

Cayratia

Cissus

Pterisanthes

Tetrastigma
Winteraceae (1)

Drimiys

$\quad$ Zingiberaceae (6)
Adelmeria
Alpinia
Globba
Kolowratia
Languas
Plagiostachys

* The application of family and genus names has been standardized based on Gunn et al. (1992).

The numbers in brackets refer to the number of genera so far identified within the respective families.

Table 5. Families and genera of pteridophytes identified on Mt. Pangasugan based on the synthesis of the studies by Belonias and Bañoc (1994) and Langenberger $(2003)^{*}$

Aspidiaceae

Ctenitis

Cyclopeltis

Heterogonium

Pleocnemia

Pteridrys

Tectaria

Aspleniaceae

Asplenium
Athyriaceae

Diplazium

Blechnaceae

Blechnum

Stenochlaena

Cyatheaceae

Cyathea

\section{Davalliaceae}

Davallia

Trogostolon

\section{Dennstaedtiaceae}

Dennstaedtia

Microlepia

Dryopteridaceae

Didymochlaena 
Table 5. Families and genera of pteridophytes identified on Mt. Pangasugan based on the synthesis of the studies by Belonias and Bañoc (1994) and Langenberger $(2003)^{*}$

Gleicheniaceae

Dicranopteris

Gleichenia

Grammitidaceae

Calymmodon

Scleroglossum

Hymenophyllaceae

Trichomanes

Hymenophyllum

Lindsaea

Sphenomeris

Tapeinidium

Lycopodiaceae

Lycopodium

Lomariopsidaceae

Bolbitis

Elaphoglossum

Lomogramma

Teratophyllum

Marattiaceae
Angiopteris
Marattia

Oleandraceae

Nephrolepis

Oleandra

$\begin{array}{cl}\text { Osmundaceae } & \text { Adiantum } \\ \text { Osmunda } & \text { Pytyrogramma } \\ & \text { Syngramma } \\ \text { Parkeriaceae } & \text { Taenitis }\end{array}$

Ceratopteris

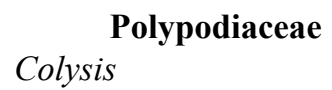

Drynaria

Leptochilus

Microsorum

Pyrrosia

Selliguea

Psilotaceae

Psilotum

\author{
Pteridaceae \\ Acrostichum \\ Pteris \\ Salviniaceae \\ Azolla \\ Salvinia
}

\section{Schizaeaceae}

Lygodium

\section{Thelypteridaceae}

Amphineuron

Chingia

Christella

Cyclosorus

Macrothelypteris

Pneumatopteris

Pronephrium

Pseudophegopteris

Sphaerostephanos

\section{Vittariaceae}

Antrophyum

Vittaria
Selaginellaceae

Selaginella

Sinopteridaceae

Pytyrogramma

Taenitis

Vittaria 
Table 6. Classes and genera of bryophytes identified in the foothills of Mt. Pangasugan (from Quimio, 1994)

Class Musci

Acroporium

Anomobryum

Barbula

Bryum

Buxbaumia

Calymperes

Calytothecium

Campylopus

Clastrobryum

Dicranella

Dicranoloma

Fissidens

Hypnum

Macromitrium

Macromitrium

Neckeropsis

Neckeropsis

Orthodontium

Orthotrichum

Plagiopus

Ptychomitrium

Symphysodontella

Taxithellium

Zygodon

\section{Class Hepaticae}

Aneura

Apometzgeria

Apotreubia

Bazzania

Blasia

Cyathodium

Frullania

Lejeunea

Lophocolea

Marchantia

Metzgeria

Pellia

Riccia
Class Anthocerotae
Anthoceros

Class Anthocerotae
Anthoceros . 
that Mt. Pangasugan and the Leyte Cordillera deserve more attention. Although the Herbarium of the Visayas State University suffers a low budget - as it is typical not only for many tropical Herbaria - it is well equipped and provides good working facilities at the foot of a fascinating mountain.

\section{ACKNOWLEDGEMENTS}

The authors wish to especially thank the following: Ms. Jannes Detablan and Ms. Marie Macanas for their assistance in the processing of backlog specimens and encoding of the Herbarium data; and the various researchers and students who have worked on the flora of Mt. Pangasugan. Additionally, many of the taxa provided in Annex 1 could be added as a result of a research grant to the first author by the A.F.W. Schimper Foundation, Hohenheim, Germany.

\section{REFERENCES}

ASIO, V. 1996. Characteristics, Weathering, Formation and Degradation of Soils from Volcanic Rocks in Leyte, Philippines. Hohenheimer Bodenkundliche Hefte 33, Univ. Hohenheim, Stuttgart, Germany. 209 pp.

BELONIAS, B. S. 2002. The dicot flora on the western slopes of Mt. Pangasugan, Leyte Island, Philippines. PhD Thesis, University of the Philippines, Los Banos, Philippines. 133 pp.

BELONIAS, B. S. and L. M. BAÑOC. 1994. Species diversity and distribution of pteridophytes in Mt. Pangasugan, Leyte, Philippines. Annals of Tropical Research 16(2):30-38.

DENR and UNEP. 1997. Philippine Biodiversity: An Assessment and Action Plan. Bookmark Inc., Makati City, The Philippines. 298 pp. 
DICKERSON, R. E. 1928. Distribution of Life in the Philippines, Reprinted 1975, The Bookmark Inc., Manila. 322 pp + figures.

FESSEL, H. H. and LUECKEL. 1996a. Dendrobium milaniae. Die Orchidee 47(3):A131.

FESSEL, H. H. and LUECKEL. 1996a. Flickingeria junctilobia. Die Orchidee 49(5):251.

FESSEL, H. H. and LUECKEL. 1996b. Dendrobium orbilobulatum. Die Orchidee 47(5): A232.

FESSEL, H. H. and LUECKEL. 1997. Dendrobium balzerianum. Die Orchidee 48(4): 173.

FRODIN, D. G. 2001. Guide to Standard Floras of the World, 2nd ed. Cambridge University Press, Cambridge. 1100 pp.

GUNN, C. R., J. H. WIERSEMA, C. A. RITCHIE, and J. H. KIRKBRIDE JR. 1992. Families and Genera of Spermatophytes Recognized by the Agricultural Research Service. U.S. Department of Agriculture, Technical Bulletin No 1796. 500 pp.

KARTAWINATA, K. 1990. A review of natural vegetation studies in Malesia, with special reference to Indonesia. In: The Plant Diversity of Malesia. Proceedings of the Flora Malesiana Symposium, Leiden (P. Baas, K. Kalkman, and R. Geesink, eds). August 1989. Kluwer Academic Publishers, The Netherlands, pp. 120-132.

KINTANAR, R. L. 1984. Climate of the Philippines. PAGASA, Quezon City, Philippines, September 1984, 38 pp.

LANGENBERGER, G.2003.Diversität, StrukturundReliefabhängigkeit der Vegetation in einem Tieflandregenwald der Insel Leyte, 
Philippinen. Dissertation. Institute of Plant Production and Agroecology in the Tropics and Subtropics (380), University of Hohenheim. 181 pp.

MADULID, D. A. and M. G. AGOO. 1992. A bibliography on Philippine Biodiversity: Part I - Plants. National Museum, Manila, Philippines. 189 pp.

MERRILL, E. D. 1945. Plant life of the Pacific world. The Macmillan Company, New York, US. 295 pp.

MYERS, N., R. A. MITTERMEIER, C. G. MITTERMEIER, G. A. B. DA FONSECA, and J. KENT. 2000. Biodiversity hotspots for conservation priorities. Nature 403:853-858.

ONG, P. S., L. E. AFUANG, and R. G. ROSELL-AMBAL. 2002. Philippinebiodiversityconservationpriorities:aseconditeration of the National Biodiversity Strategy and Action Plan. DENRPAWB, Conservation International Philippines, Biodiversity Conservation Program-University of the Philippines Center for Integrative and Development Studies, and Foundation for the Philippine Environment, Quezon City, Philippines. 113 pp.

PO, P. 2000. Altitudinal distribution, diversity and abundance of the monocotyledonous flora of Mt. Pangasugan, Leyte. M.S. Thesis, University of the Philippines, Los Baños, Laguna, Philippines.

QUIMIO, C. A. 1994. Bryophytes of river valleys and kaingin areas of Mt. Pangasugan, Leyte, Philippines. Annals of Tropical Research 16(2):39-45.

PRANCE, G. T., H. BEENTJE, J. DRANSFIELD, and R. JOHNS. 2000. The Tropical flora remains undercollected. Ann. Missouri Bot. Gard. 87:67-71. 
SALGADO, A. E. 1990. A checklist of Philippine ferns. Philipp. J. Sci. 119(2):107-148.

SOERIANEGARA, I. and R.H.M.J. LEMMENS. 1994. Plant Resources of South-Est Asia No. 5(1): Timber Trees: Major commercial timbers. Prosea Foundation, Bogor, Indonesia \& Pudoc-DLO, Wageningen, the Netherlands. 610 pp.

VAN STEENIS, C. G. G. J. 1950. Chronology of the collections. Pp. LXXVI-CVI. In: Flora Malesiana Series I, Vol. 1. (C. G. G. J. van Steenis, ed).

ZIKELI, S. 1998. Nutrient status and nutrient cycles of the tropical rainforest, Mt. Pangasugan, Leyte, Philippines. Diplomarbeit, Landwirtschaftliche Fakultät, Inst. f. Bodenkunde u. Pflanzenernährung, Martin-Luther-Universität HalleWittenberg. $101 \mathrm{~S}$. 